\title{
Evaluation of the Cost of Ecosystem Services of Urban Landscapes (by the Example of Moscow)
}

\author{
O. V. Semenyuk ${ }^{a}$ * , G. V. Stoma ${ }^{a}$, and K. S. Bodrov ${ }^{a}$ \\ ${ }^{a}$ Lomonosov Moscow State University, Moscow, 119991 Russia \\ *e-mail: olgatour@rambler.ru \\ Received March 16, 2021; revised July 6, 2021; accepted July 7, 2021
}

\begin{abstract}
The cost of park-recreational, residential, and residential-transport urban landscapes of Moscow has been estimated taking into account land use and the relationships between ecosystem services and ecological functions and properties of individual landscape components. On the basis of the methodology previously proposed by the authors, a wide range of ecosystem services of urban landscapes, mainly associated with soils and their ecological state, has been assessed. The cost of ecosystem services provided by the soil in urban landscapes is 20-30 times higher in comparison with that of green spaces, and some soil services can be considered invaluable because of the difficulty of renewing this natural resource. The cost of ecosystem services of undisturbed soils of park and recreational landscapes is 1.5-2 times higher than that of anthropogenically transformed soils of residential and residential-transport urban territories. The main contribution to the overall cost of ecosystem services of soils in urban landscapes is due to the following services: carbon sequestration, preservation of the genetic material of biota, and filtration and accumulation of chemical elements in the ecosystem. These services can be considered as promising in the monetization of ecosystem services in urban landscapes. The decline in the cost of ecosystem services from park and recreational landscapes to residential and residential-transport landscapes is largely determined by the deterioration of the ecological state of soils. The benefits provided by the natural block of landscapes are comparable to or greater than those of the cultural (human-created) block. In relation to the all-Russia assessment of ecosystem services, a specific feature of urban areas is a significant share (on average, 25\%) of the cultural block in the total cost of ecosystem services and a decrease in the cost of regulatory services by about $30 \%$. The results of the economic assessment of ecosystem services of urban landscapes indicate an underestimation of the value of natural components, a significant contribution of soil to the natural block, the need to search for simplified integral indicators of its state, and the presence of cost calculation problems. The methodological approaches and provisional results of this study can be used in urban planning with the aim to preserve the soil cover of urban landscapes and optimize their functioning.
\end{abstract}

Keywords: ecosystem services, functions of urban landscapes, ecological state of soils, Albic Retisols, Urbic Technosols, Albic Luvisols

DOI: $10.1134 / \mathrm{S} 1064229321120103$

\section{INTRODUCTION}

The implementation of the idea of sustainable development of human society and the biosphere involves the regulation of human activities using economic mechanisms, one of which is the valuation of natural resources and ecosystem services [23, 34, 43, 45]. The assessment of the value of particular ecosystems is an important applied problem; moreover, it implies the solution of many fundamental scientific issues.

Ecosystem services (ESs) are economic benefits for consumers based on the provision of various kinds of functions by nature. The concept of ecosystem services was formulated in the late 1990s in order to give an economic sound to the traditional problems of nature protection, environmental security, and ecological functions of natural and natural-technogenic ecosystems. It is grounded in the concept of natural resource potential [4, 39-41, 47].

Currently, there are several classifications of ecosystem services. They are fundamentally similar and are built on some compromise between two main approaches: the first comes from the benefits that a person receives from nature, and the second is based on the characteristics of natural systems and their functions [40]. Ecosystem services are divided into 3 groups: provisioning, regulatory, and cultural. Sometimes, a group of supporting services is singled out, including such services as soil formation, biological turnover of elements, and photosynthesis. This category is not directly assessed, but is seen as a necessary condition for the production of all other services. It pays special attention to biodiversity as a characteristic of ecosystems that affects almost all ESs [39-41, 47]. 
The lack of a unified, well-established methodology and approach to the assessment of ES at the present time leads to the results that differ for some services by dozens of times. When determining ecosystem services of territories of the same land use, different parameters of ecosystems can be taken into account [4]. In a number of works, attention is focused on the assessment of biodiversity, but the mechanism of cost calculation is not proposed. It has been shown that the correlations between indicators of species richness and ecosystem services do not reflect the causal relationships between them [40, 42, 45].

According to the grain-focus-extent concept, research is carried out taking into account the analysis of ecosystem services on three scales: global, regional, and local. Various approaches to assessing ecosystem services at the federal and regional levels are presented in the prototype of the national report on ecosystem services in Russia (for terrestrial ecosystems) [40]. The estimates obtained are illustrations of possible approaches. They show the importance of the development of a system for assessing ecosystem services and integrating their value into the economy and decisionmaking in Russia [39, 40]. However, the benefits obtained at these scales often do not fit one another [3].

The main object of research at the regional level is represented by natural parks and specially protected natural areas. In most cases, the valuation procedure is reduced to assessing plant community, while other landscape components receive insufficient attention $[13,26,41,42,50]$. In some studies, the role of forests and wetlands in carbon sequestration is taken into account, and in some cases cultural services (tourism) are estimated $[35,36]$.

When assessing ESs of agricultural lands, their "tolerance to erosion" and their role in the "accumulation of chemical compounds" are often considered $[5,36]$.

Approaches to assessing soil ecosystem services deserve special attention. The participation of soil scientists in these studies is modest, and the understanding on this issue is somewhat different from the works of ecological and economic orientation. Attempts to reconcile ideas about different functions of soils with their economic assessment based on proven principles are rare. It is assumed that "... soil scientists, with their inherent systemic vision of nature, can contribute to the economic assessment of the resource potential and, in some cases, correct the existing groundless assessments" [15, p. 29].

The framework for the approach to assess soil services was developed by Dominati et al. in 2010 (cited from [15]). These services as a whole have been taken into account in a few works performed in Russia [5, 27, 36]. In a number of approaches, soil formation and element turnover are considered as supporting services and are not directly assessed. At the same time, interest in soil services is significant, since changes in the quality of ecosystem services are often associated with the direct impact of humans on soils [15].

In connection with the active growth of cities, the assessment of the value of ecosystem services in urbanized territories is particularly relevant. Currently, it is at the initial stage of development, and research is performed at the regional or local level. In urban environments, anthropogenic activity shapes elementary urban landscapes, which are distinguished according to the criteria of belonging to the particular land use (functional) zone, the level of technogenic impact, and the nature of transformation of the biological cycle. Thus, park-recreational, residential, residential and transport, industrial, and agroindustrial (agrotechnogenic) landscapes can be distinguished [38]

For urban landscapes, the identification of services performed by green spaces and approaches to their assessment and payment mechanisms are being developed [2, 3, 20, 24]. Usually, only air purification and recreation services are assessed [40].

Despite a significant amount of data on urban soils $[8,16-18,25,28,37,38,46,49,51,52]$, insufficient attention is paid to the assessment of ecosystem services of the soil component of ULs. Soil transformation in ULs affects the performance of ecological functions by soils, which cannot but affect ESs of urban territories.

The theory of the ecological functions of soil in ecosystems and the global functions of the soil cover in the biosphere has been developed by Russian soil scientist in the recent decades [11, 22, 32]. This theoretical approach makes it possible to assess the role of soil in the biosphere from a new angle. It can be designated by the triad: factors-soils-ecological functions. Soil ecosystem functions are understood as the participation of soil in the life biogeocenoses, elementary units of the biosphere. Ecosystem functions of soils are divided into two main categories: (1) ecosystem (biogeocenotic) and (2) global (biospheric and ethnospheric). Further development of this classification scheme has resulted in separation of the following categories of soil ecological functions: biogeocenotic; lithospheric, hydrospheric, atmospheric, general biospheric, and ethnospheric. These functions are controlled by three groups of soil properties: physical, chemical, and biological [22, 32].

The broadening of our understanding of ecosystem services and ecological functions of soils and the deterioration of the ecological situation in megacities pose the problem of developing an efficient mechanism for land use regulation. It is important to choose ESs and the corresponding functions of ecosystems (including soils) that are most sensitive to human impact, and whose changes affect the quality of the habitat. Methods for assessing the ecological state of soils in urban areas have been developed and tested [19, 28-31, 37]. The ecological state of soils is understood as a set of soil properties that determines the degree of soil com- 
pliance with natural and climatic conditions of soil formation and suitability for sustainable functioning of natural and anthropogenic ecosystems [19]. The ecological state of soils undoubtedly affects the quality of ESs in urban landscapes.

Despite the insufficient development of research into the allocation, accounting, and evaluation of ESs, certain environmental issues for urbanized territories can be partially resolved. Some disadvantages of the proposed approaches should be noted: quantification (numerical calculation) of ESs does not take into account the dependence of the value of ESs on the functional use of the territory and the ecological state of landscapes and their individual components. This disadvantage manifests itself in the absence of estimates of the contribution of soils responsible for the implementation of a wide range of ecosystem services and, in contrast to vegetation, being a long-renewable resource.

The formation of an artificial environment and the loss of natural landscapes in urbanized areas as a result of urban development determines the relevance of works on the quantitative assessment of the loss of the ability to perform ecosystem functions and ecosystem services by urban landscapes. The aim of our study is to assess the ecosystem services of urban landscapes with due account for the ecological functions of soils.

\section{OBJECTS AND METHODS}

The objects of the study were park-recreational (PRL), residential-transport (RTL), and residential (RL) landscapes of the Southwestern Administrative okrug of Moscow. Park-recreational landscapes include conventionally undisturbed or slightly disturbed territories of the Bitsevsky Les (forest) natural-historical park; residential areas include the space near residential buildings and consist of different microzones (front gardens, sports grounds, parking lots, etc.); and residential-transport areas include the zones located within $5 \mathrm{~m}$ from highways. The Bitsevsky forest is mainly composed of broadleaved tree species with a dominance of linden and oak and with developed undergrowth and young growth; the herbaceous layer is characterized by a large number of species of the forest ecocenotic group [16]. In the residential and residential-transport landscapes, the area of green spaces reaches 35 and $45 \%$, respectively; linden, birch, and mountain ash predominate in group and linear plantations; undergrowth is virtually absent. Shrubs (elderberry, lilac, mock-orange, spirea) are common in residential landscapes. The herbaceous layer mainly consists of meadow and weed-ruderal species.

A wide range of soils were diagnosed in the urbanized area. Native soddy-podzolic soils (Albic Retisols) predominate in the Bitsvesky forest [16-18], there are also light gray forest soils (Luvisols) and some intergrades between these two soil groups. In the residential-transport and residential areas, urbanozems, urbostratozems, and urboquasizems (Urbic Technosols) predominate $[8,14,25,53]$.

Algorithm for evaluation of ecosystem services. To assess ecosystem services, we used a methodological approach based on the identification of the features of functional use of urban landscapes (land use), finding the relationships between ecosystem services and functions and the state of some components of urban landscapes, and the choice of appropriate methods for their economic valuation. The methodology for the economic assessment of ESs earlier developed by the authors for the Bitsevsky forest [27] has been modified to be applied to other urban landscapes. The main focus of this study is on such landscape components as vegetation and soils.

Analysis of ecosystem functions of urban landscapes. To identify the ecological functions of urban landscapes, the classification of soil functions according to Dobrovol'skii and Nikitin was applied [22, 32]. As soil is an integral component of landscape, soil functions at different hierarchical levels reflect well the functions of the latter. In the context of our study, it was important to choose appropriate taxonomic units of soil functions.

The choice of ecosystems services was performed using the CICES classification [4], as this classification contains a significant cluster of ESs associated with soil.

Methods of the study of landscape components. In the studied landscapes, test plots were laid in identical geomorphic positions. Overall, we studied 5 plots in PRL, 9 plots in RL, and 5 plots in RTL. Characteristic features of the natural soils in the PRL (Bitsevsky forest) were studied in auger samples to a depth of $1 \mathrm{~m}$; small soil pits were described in RTL and RL. For analytical work, soil samples were taken in ten replicates from the layers of $0-10$ and $10-20 \mathrm{~cm}$.

Determination of soil properties. The soil reaction $\left(\mathrm{pH}_{\text {water }}\right)$ and electrical conductivity in soil water $(1: 2)$ extracts (Cond-315i handheld meter), $\mathrm{C}_{\text {org }}$, and bulk density were determined according to routine methods $[6,7]$. The biological activity of soils (basal respiration) was assessed using an LKhM80 (Khrom 4 modification) gas chromatograph [21]. The number, biomass, and group composition of soil invertebrates were counted in three replicates in manually disintegrated soil monoliths (undisturbed samples) from the area of $1.16 \mathrm{~m}^{2}$ in the layers of $0-10$ and $10-20 \mathrm{~cm}[9,12]$; the diversity of soil invertebrates was assessed by the Shannon index [10]. The results were processed using the Statistica 10 software at a confidence level of 0.95 .

To characterize plant resources, the aboveground phytomass of tree plantations was determined [1]. The erosion resistance of the territory was assessed on the basis of field observations over the area occupied by tree plantations [40]. The amount of atmospheric dust absorbed by tree plantations was calculated on the basis of data on dust retention by one tree in urban 
conditions (on average, $25 \mathrm{~kg}$ ) [38] and the number of trees per 1 ha (400 in PRL, 180 in RTL, and 140 in $\mathrm{RL})$. The carbon $\left(\mathrm{C}-\mathrm{CO}_{2}\right)$ sequestration was estimated using the Ex-Act calculator [44] and taking into account the area of the landscape occupied by green spaces.

Ecological state of the soils was determined by the method of Stroganova et al. [31]. From the proposed indicators, the reduction in the thickness of humus layer and carbon stock, bulk density, texture, $\mathrm{pH}_{\text {water }}$, electrical conductivity values, and the decrease in the soil biological activity and in the diversity of the soil mesofauna were selected. Depending on the level of change in the corresponding property relative to its optimum or relative natural analogues, an assessment was made on a five-point scale (optimum, 5; critical, 1) and multiplied by the weight coefficient of the property's significance $(0.5-2.5)$. The obtained partial coefficients $B_{i} K_{i}$ can serve as an indicator of the change in a given indicator and further used in the economic assessment of individual ESs.

Valuation methods for ecosystem services. To monetize ESs associated with environmental functions, the following methods were used: market prices, cost, and damage prevention cost. The block of cultural services was assessed by polling the population (over 100 respondents) $[4,50]$. Data on the cost of earthworms, standing forest, and soil with the same carbon content were used in the calculations. Services related to the emission or sequestration of carbon or $\mathrm{CO} 2$ were assessed on the basis of European estimates of $\mathrm{CO}_{2}$ emission quotas. In the cost method, the cost of soil cleaning (remediation) from the accumulated pollutants by the electrokinetic method was estimated. The cost of cleaning from dust was determined using operating costs of the protection of atmospheric air from pollutants [36].

The economic assessment of ecosystem services was given using an integrated approach proposed by Peirce [48], according to which the total economic value of ESs is the sum of the costs of their use and non-use.

The specific value of urban landscapes was determined as the sum of the provided ESs per unit area. The calculation of the provisioning and regulating ESs was carried out according to the formula:

$$
\mathrm{SVES}=\Sigma\left(X_{i, 1} \times B_{i} K_{i, 1} / B_{i} K_{i, \max }\right),
$$

where SVES is the specific value of ESs of a given urban landscape, $X_{i, 1}$ is the specific (per $1 \mathrm{ha}$ ) economic value of a given $i$ th service; $B_{i} K_{i, 1}$ is the ecological estimate of a given indicator of the landscape; and $B_{i} K_{i, \max }$ is the ecological estimate of the optimum state of this indicator.

\section{RESULTS AND DISCUSSION}

The applied algorithm for assessing ESs includes the following stages: (1) determination of the ecologi- cal functions of urban landscapes in relation to their functional purpose (land use); (2) determination of the relationships between the ecological functions and ESs and the state of landscape components; (3) assessment of the ecological state of individual natural components with due account for the degree of their transformation in the urban landscape; and (4) economic valuation of ESs. A similar sequence of stages was presented in [39].

Choice of ecological functions. At the first stage of the algorithm for assessing ESs, ecological functions implemented through the functions of landscape components, including soils, were identified. Two groups of functions are distinguished: ethnospheric and ecosystem functions. Ethnospheric functions reflect the social aspects of the life of urban population: the location of residential buildings, transport network, recreational areas, etc. Ecosystem functions specify the functioning of natural components and provide comfortable conditions for the urban environment.

Taking into account the expansion of the functional purpose of urban areas, the category of ethnospheric functions has been supplemented with aesthetic, environmental education, and public awareness functions. The latter function reflects the growing interest of society in topical environmental problems and serves as a link between ethnospheric and ecosystem functions. The list of particular ecological functions has been expanded, which is associated with the active promotion of the tasks of preserving natural biodiversity and sustainable development of cities.

Being natural and anthropogenic objects, the studied types of urban landscapes perform the whole range of ecosystem functions. In accordance with the specificity of particular urban landscapes and their functional role, priority functions have been selected (Table 1).

Among the ethnospheric functions of the RTL, the function of provisioning transit of the population and various types of transport predominates. These landscapes are considered as objects of applied research to assess the impact of transport on the ecological state of the urban environment. The latter is also typical for the SL, but their main purpose of this landscape is to host residential buildings and active recreation areas. Residential landscapes also perform aesthetic functions that determine the emotional perception of their appearance, which is taken into account in design decisions on spatial organization of the urban environment. Aesthetic functions, as well as recreational functions, are fully realized in the PRL-valuable urban areas with preserved undisturbed or weakly transformed ecosystems, which largely determines the scientific interest in them and the active conduct of scientific research. Landscapes of this type are the basis for the organization of environmental education and promotion of public awareness.

In contrast to ethnospheric functions, ecosystem functions are performed by all types of landscapes. 
Table 1. Priority ethnospheric and ecosystem functions of urban landscapes

\begin{tabular}{l|c|c|c}
\hline \multirow{2}{*}{ Functions of landscape } & \multicolumn{3}{|c}{ Urban landscapes } \\
\cline { 3 - 4 } & $\begin{array}{c}\text { park- } \\
\text { recreational }\end{array}$ & residential & $\begin{array}{c}\text { residential- } \\
\text { transport }\end{array}$ \\
\hline
\end{tabular}

Ethnospheric functions

Allocation of residential buildings

Ensuring the transit of population and vehicles

Recreational

Environmental education and awareness

Esthetic

Environmental research

Ecosystem functions

Preservation of biodiversity (natural phytocenoses and Red Data Book species)

Maintenance of favorable habitats for biota

Regulation of the composition, structure, and dynamics of biogeocenoses

Accumulation and transformation of matter and energy in biogeocenoses

Sanitary function (buffer and protective screen of biogeocenoses)

Regulation of water turnover and composition and regime of atmospheric gases

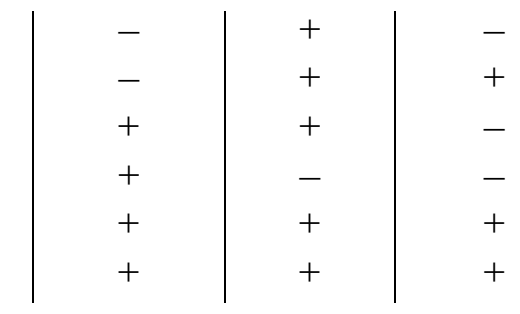

-
+
-
-
+
+

\begin{tabular}{l|l|l}
+ & - & - \\
+ & - & - \\
+ & - & + \\
+ & + & + \\
+ & + & + \\
+ & + & + \\
\hline
\end{tabular}

Urban landscapes include all natural components (vegetation, soils, water bodies, etc.) that ensure the implementation of the main ecological functions: "accumulation and transformation of matter and energy in the biogeocenosis," "regulation of moisture circulation," "regulation of gas regime and composition of the atmosphere," and "buffer and protective screen of biogeocenoses." The function of "forming a favorable biota habitat" is characteristic of all urban landscapes, but each has its own specificity.

Landscapes components in the RL and RTL are largely formed artificially and differ from those in the conditionally natural Bitsevsky forest. In anthropogenically transformed landscapes, the function of "regulating the composition, structure, and dynamics of biogeneoses" is also realized. However, the artificial formation of green spaces and their careful management (simplification of the vertical structure of phytocenoses, mowing of grass stand, collecting litter, replacing lawn coverings and soil, etc.) largely levels the results of natural processes in the biogeocenoses [33].

With respect to the ecological functions, a special place belongs to the PRL. Taking into account the presence of undisturbed ecosystems, the function of "preservation of biodiversity" (Red Data Book species of biota, natural phytocenoses, and soils) is only realized in these territories, which determines their significant ecological value.

The choice of ecosystem services provided by urban landscapes was carried out taking into account the performance of ecological functions by soil and vegetation. It was based on the possibility of comparing them with the ecological functions of landscape com- ponents, in particular, the functions of soils and the soil properties responsible for their implementation. Ecosystem functions are associated with provisioning and regulatory services, while ethnospheric functions are associated with cultural services.

Among 23 ESs included in the CICES classification, 10 services were selected (Table 2), which is significantly more than the number of services presented in other studies $[5,36,39,40]$. The list of services was structured according to their hierarchical position down to the type level, in accordance with three main sections: provisioning, regulating, and cultural services [41]. In the classification used, the largest number of ESs are included in the regulating section; they comprise a half of the list of ESs of urban landscapes. Among the provisioning services, "genetic material of the biota" correlates with the function of soils, which determines the conditions of the environment; in particular, the diversity and abundance of soil mesofauna (Table 3). The function of "regulating the gas regime and the composition of the atmosphere" is largely determined by the reserves of plant resources and, in part, by the biological activity of soils.

Regulatory services are related to soil functions such as "buffer and protective barrier," "erosion control," "accumulation and transformation of matter and energy," and "soil fertility." Vegetation plays a leading role in the implementation of the most important service of regulating the composition of the atmosphere and climate.

Cultural services include recreation and entertainment (walks, recreation on sites, etc.), sensory perception of nature, aesthetic pleasure, the value of exis- 
Table 2. Ecosystem functions and ecosystem services and urban landscapes and methods of their economic valuation

\begin{tabular}{|c|c|c|c|}
\hline \multirow{2}{*}{$\begin{array}{l}\text { Ecosystem functions of } \\
\text { landscape and its } \\
\text { components }\end{array}$} & \multicolumn{2}{|c|}{ Hierarchical levels of ecosystem services } & \multirow{2}{*}{$\begin{array}{c}\text { Method of economic } \\
\text { valuation of ecosystem } \\
\text { services }\end{array}$} \\
\hline & group & class/type & \\
\hline
\end{tabular}

\begin{tabular}{|c|c|c|c|}
\hline \multicolumn{4}{|c|}{ Section: Provisioning services; division: materials } \\
\hline $\begin{array}{l}\text { Habitat; regulation of the } \\
\text { composition and structure } \\
\text { of biogeocenoses }\end{array}$ & Biomass & $\begin{array}{l}\text { Genetic material of biota/genetic material } \\
\text { of trees, shrubs, herbs, animals, birds, and } \\
\text { microorganisms; species included in the Red } \\
\text { Data Books are considered separately }\end{array}$ & Market price method \\
\hline \multicolumn{4}{|c|}{ Section: Provisioning services; division: energy } \\
\hline $\begin{array}{l}\text { Regulation of gas regime } \\
\text { and composition of the } \\
\text { atmosphere }\end{array}$ & Biomass energy & Major vegetation resources/total wood stock & Market price method \\
\hline \multicolumn{4}{|c|}{ Section: Regulating services and sustainability; division: fluxes } \\
\hline Erosion control & Matter fluxes & $\mid \begin{array}{l}\text { Stability of the mass of matter; control of the } \\
\text { level of erosion/preservation of the soil cover } \\
\text { stability and vegetation in the areas of } \\
\text { increased erosion hazard }\end{array}$ & $\begin{array}{l}\text { Method of damage preven- } \\
\text { tion cost }\end{array}$ \\
\hline Sanitary & & $\begin{array}{l}\text { Evaporation and air cleaning/ air cleaning } \\
\text { from technogenic dust particles }\end{array}$ & $\begin{array}{l}\text { Cost of measures to control } \\
\text { air pollution }\end{array}$ \\
\hline \multicolumn{4}{|c|}{$\begin{array}{l}\text { Section: Regulating services and sustainability; division: } \\
\text { maintenance of the physical, chemical, and biological conditions }\end{array}$} \\
\hline $\begin{array}{l}\text { Buffer and protective bar- } \\
\text { rier }\end{array}$ & Soil formation & $\begin{array}{l}\text { Filtration and accumulation of chemical ele- } \\
\text { ments/accumulation of heavy metals, oil prod- } \\
\text { ucts, etc. }\end{array}$ & Replacement cost method \\
\hline $\begin{array}{l}\text { Accumulation and trans- } \\
\text { formation of matter and } \\
\text { energy; soil fertility }\end{array}$ & & $\begin{array}{l}\text { Weathering and soil formation pro- } \\
\text { cesses/activity of soil biota; chemical and } \\
\text { physical pedogenesis }\end{array}$ & \\
\hline \multicolumn{4}{|c|}{ Section: Cultural services; division: physical and intellectual interaction with landscape components. } \\
\hline $\begin{array}{l}\text { Ethnospheric (recre- } \\
\text { ational) }\end{array}$ & $\begin{array}{l}\text { Physical and } \\
\text { experimental } \\
\text { interactions }\end{array}$ & $\begin{array}{l}\text { Direct physical use of landscape for various } \\
\text { purposes/recreation, outdoor activities, paths } \\
\text { and clearings }\end{array}$ & $\begin{array}{l}\text { Subjective valuation } \\
\text { method }\end{array}$ \\
\hline $\begin{array}{l}\text { Ethnospheric (recre- } \\
\text { ational) }\end{array}$ & $\begin{array}{l}\text { Intellectual } \\
\text { interaction }\end{array}$ & Recreation/nature festivals, sports, races, etc. & \\
\hline Ethnospheric & & $\begin{array}{l}\text { Aesthetic enjoyment/sense of closeness to } \\
\text { nature, source of inspiration }\end{array}$ & \\
\hline \multicolumn{4}{|c|}{ Section: Cultural services; division: spiritual and symbolic interaction } \\
\hline Ethnospheric & $\begin{array}{l}\text { Other cultural } \\
\text { effects }\end{array}$ & The value of existence/presence of ES per se & $\begin{array}{l}\text { Subjective valuation } \\
\text { method }\end{array}$ \\
\hline
\end{tabular}

tence (awareness of the satisfaction of having a park, regardless of whether it is possible to visit it) and physical (direct) use of the landscape for other purposes.

Monetization of services for "preservation and provision of genetic material of the biota," "basic plant resources" (wood reserves), "sustainable protected existence" (reserved areas), and "climate regulation" (based on international estimates of greenhouse gas quotas) was carried out by the market price method used in the assessment of ESs having analogues of goods or services on the existing market. In cases, where an ES does not have an analogue on the existing market for goods and services and indirect estimates of its cost are required, two methods were used: replacement cost and cost of preventing damage. The replacement cost method is used to estimate the costs to be incurred if the ecosystem ceases to provide a given service. For example, if the soil is unable to accumulate and filter pollutants (purification function), the cost of replacement of the soil layer for achieving acceptable concentrations of the pollutants is taken into account. This method evaluates the ser- 
Table 3. Ecosystems services and indicators of the ecological state of soils in the studied urban landscapes

\begin{tabular}{|c|c|c|c|c|c|c|c|c|c|c|}
\hline \multirow{3}{*}{ Class of ESs } & \multirow{3}{*}{ Soil indicator } & \multicolumn{3}{|c|}{$\begin{array}{c}\text { Indicator value } \\
\text { in different urban } \\
\text { landscapes }\end{array}$} & \multicolumn{3}{|c|}{$\begin{array}{l}\text { Point estimate, } \\
\text { B1 }\end{array}$} & \multicolumn{3}{|c|}{$B_{i} K_{i}$} \\
\hline & & \multicolumn{9}{|c|}{ urban landscape } \\
\hline & & PRL & RL & RTL & PRL & RL & RTL & PRL & $\mathrm{RL}$ & RTL \\
\hline \multicolumn{11}{|c|}{ Provisioning services } \\
\hline \multirow[t]{2}{*}{$\begin{array}{l}\text { Genetic material of } \\
\text { the biota }\end{array}$} & $\begin{array}{l}\text { Abundance of soil mesofauna in the layer } \\
\text { of } 0-20 \mathrm{~cm} \text {, species } / \mathrm{m}^{2}\end{array}$ & & 192 & 172 & 5 & 3 & 2 & 5 & 1.5 & 1 \\
\hline & $\begin{array}{l}\text { Diversity of soil mesofauna (Shannon } \\
\text { Index), units }\end{array}$ & 3.47 & 1.90 & 2.42 & 5 & 3 & 3 & 5 & 1.5 & 1.5 \\
\hline \multicolumn{11}{|c|}{ Regulating services and sustainability } \\
\hline \multirow{6}{*}{$\begin{array}{l}\text { Filtration and accu- } \\
\text { mulation of chemical } \\
\text { elements in the eco- } \\
\text { system }\end{array}$} & $\begin{array}{l}\text { Bulk density in the layer of } 0-10 \mathrm{~cm} \text {, } \\
\mathrm{g} / \mathrm{cm}^{3}\end{array}$ & 1.05 & 1.22 & 1.19 & 5 & 4 & 5 & 5 & 4 & 5 \\
\hline & $\begin{array}{l}\text { Electrical conductivity of soil solution, } \\
\mathrm{dS} / \mathrm{m}\end{array}$ & 0.11 & 0.14 & 0.12 & 5 & 5 & 5 & 6 & 5 & 5 \\
\hline & $\mathrm{pH}_{\text {water }} 0-20 \mathrm{~cm}$ & 6.2 & 6.8 & 6.8 & 4 & 5 & 5 & 4 & 5 & 5 \\
\hline & $\begin{array}{l}\text { Particle-size distribution; } \% \text { of fractions } \\
<0.01 \mathrm{~mm}\end{array}$ & 23 & 35 & 30 & 5 & 4 & 4 & 5 & 6 & 6 \\
\hline & $\begin{array}{l}\text { Reduction of carbon stock in the layer } \\
\text { of } 0-20 \mathrm{~cm}, \mathrm{t} / \mathrm{ha}\end{array}$ & No & 25 & 10 & 5 & 3 & 5 & 7.5 & 3 & 5 \\
\hline & $\begin{array}{l}\text { Total heavy metal concentration (THMC, } \\
\text { units)* }\end{array}$ & 6.6 & 12 & 22 & 5 & 5 & 4 & 5 & 12.5 & 10 \\
\hline $\begin{array}{l}\text { Stability of the mass } \\
\text { of matter, erosion } \\
\text { control* }\end{array}$ & Area under tree plantations on slopes, $\%$ & 95 & 5 & None & 5 & 5 & 5 & 5 & 5 & 5 \\
\hline \multirow[t]{2}{*}{$\begin{array}{l}\text { Weathering and soil } \\
\text { formation processes }\end{array}$} & $\begin{array}{l}\text { Decrease in the thickness of organic layer, } \\
\%\end{array}$ & No & 56 & 30 & 5 & 3 & 4 & 7.5 & 4.5 & 6 \\
\hline & Biological activity $\left(\mathrm{BR}, \mu \mathrm{g} \mathrm{C}-\mathrm{CO}_{2} / \mathrm{h}\right)$ & 3.5 & 1.3 & 2.5 & 5 & 3 & 4 & 5 & 1.5 & 2 \\
\hline $\begin{array}{l}\text { Sustainable reserved } \\
\text { existence }\end{array}$ & Preservation of the profile of native soils & Yes & No & No & 5 & 1 & 1 & 7.5 & 2.5 & 2.5 \\
\hline
\end{tabular}

$B_{i}$ is the estimate of separate $i$ th diagnostic property of soil in points (5, optimum state; 1 , irreversible disturbance); $K_{i}$ is the weighted coefficient of significance of the $i$ th diagnostic property (varied from 0.5 to 2.5 depending on the particular property and the type of urban landscape (land use); $B_{i} K_{i}$ is the degree of transformation/difference of separate diagnostic property; THMC is the index characterizing the sum of heavy metal concentrations and calculated according to [31].

* Indicators suggested by the authors for the assessment of ecosystem services [9, 12].

vices of "soil formation" and "filtration and accumulation of chemical elements."

The erosion control service can be estimated by the cost of work required to eliminate disturbances in the territory upon activation of erosional processes that were previously restrained, for example, by vegetation. The method for determining the cost of damage prevention is used to assess the work aimed at preventing negative consequences that may arise from the degradation of the ecosystem and the corresponding service.

The subjective assessment method is used to assess the demand for cultural ecosystem services (direct use of the landscape for different purposes, entertainment and recreation, aesthetic pleasure, the value of exis- tence) and the amount of money that consumers are willing to pay for them.

Landscape components and ecosystem services. Provisioning and regulating ESs are largely associated with vegetation. The provisioning service evaluated in our study is associated with "plant biomass stock." To assess provisioning services "climate regulation to remove greenhouse gases," "dust absorption by tree plantations", "stability of the mass of matter and erosion control" of the landscape, we analyzed the characteristics of vegetation, which are used in similar studies as an asset [40].

Taking into account the share of landscapes occupied by green spaces, the maximum reserves of abo- 
veground phytomass were found for the Bitsevsky forest (350 t/ha); the smallest (125.5 t/ha), for courtyards; and intermediate (157.5 t/ha) for RTL (green spaces along highways). These types of urban landscapes are ranked similarly with respect to their services of dust absorption by tree plantations $(10,3.5$, and $4.5 \mathrm{t} /($ ha yr)) and carbon sequestration (240, 84, and $108 \mathrm{t} \mathrm{CO}_{2} /$ (ha yr)), respectively. The service "stability of the mass of matter and erosion control" was assessed by the proportion of the area of green plantations s on the slopes, which, according to field observations, was $13 \%$ in the PRL, $3 \%$ in the RL, and $0 \%$ in the RTL.

Ecological assessment of soil properties. Soil performs many ecological functions in ecosystems, and individual soil properties or their sets are involved in the implementation of certain ESs. Changes in these properties under the impact of various factors can lead to a change in the quality of ESs. An assessment of the ecological state of soil properties with due account for the degree of their transformation relative to the natural or optimal values is presented in Table 3. In the development of the method [27], the range of analyzed soil properties was expanded: indicators of the biological activity (basal respiration) and preservation of the profile of natural undisturbed soils were added. Among the considered soil properties, provisioning ESs largely depend on the abundance and diversity of the soil biota. The regulating service "filtration and accumulation of chemical elements in the ecosystem" correlates with a wide range of soil properties (bulk density, EC, $\mathrm{pH}$, particle size distribution, decrease in the organic carbon stock, pollution with heavy metals); the "weathering and soil formation processes" service is correlated with only two properties (decrease in the thickness of organic horizons, biological activity). A very important service for urban areas (dominated by anthropogenically transformed landscapes) is the service of "sustainable protected (reserved) existence." It was associated with the additional indicator "preservation of the profile of natural soils." Within the framework of the concept of sustainable development of the biosphere and, in particular, cities, the preservation of natural biodiversity is a necessary element. The presence of preserved natural and weakly transformed systems, including soils, in the PRL determines their extremely high ecological value, which fundamentally distinguishes them from other urban landscapes.

Soil indicators depend on the type of urban landscapes. In the PRL, all soil properties are characterized as optimal, with a maximum score $\left(B_{i}\right)$ of 5 . In the RTL and RL, the differences in soil properties relative to the optimum ( $B_{i}$ is less than 5 points) are manifested in $58-66 \%$ of cases (in 7 and 8 cases out of the total of 12 cases, respectively). In the soils of courtyards, a significant decrease in the score (from 5 to $1-3$ ) is noted for the abundance of soil biota, lower $\mathrm{C}_{\text {org }}$ stock and lower thickness of the humus horizons, lower biological activity, and higher accumulation of heavy metals; for the RTL, this decrease is only associated with a decrease in the abundance of soil biota. The reasons for such changes are numerous: disturbance of the soil profile, soil compaction as a result of recreation, direct trampling of soil mesofauna, disturbance of migration paths, application of peat-compost mixtures and sand during soil reclamation works and renewal of the upper horizons, pollution with carbon-containing, calcium-containing and other compounds $[8,16-18$, $25,28-30,37,38]$.

Next, we calculated the partial indicators of the level of transformation (differences from the optimum) $\left(B_{i} K_{i}\right)$ of specific soil properties taking into account the weighted coefficient of significance and the type of urban landscapes. In the conditionally natural area of Bitsevsky forest (the "core" of the forest park without significant recreation and other types of anthropogenic activity) with high values of the individual indicators $\left(B_{i} K_{i}=5-7.5\right)$, the ecological state of soils is assessed as favorable. In the RL and RTL, anthropogenic loads affect the abundance and diversity of soil biota, the biological activity of soils, and preservation of the soil profile $\left(B_{i} K_{i}\right.$ decreases from 77.5 to $1-2.5$ points). The deterioration of diagnostic soil parameters, such as the organic carbon stock and the thickness of organic horizons (by $2.5-4.5$ points) is noted. The transformation of other properties (except for the content of heavy metals) is estimated by one point. The transformation of soil properties is observed to the maximum extent in courtyard areas.

Economic valuation of ecosystem services. The results of ES monetization in different urban landscapes indicate that in terms of unit cost, PRL and RL are comparable (12.5 and 14.7 million rubles), and the cost of RTL is two times lower (6 million rubles) (Table 4).

In the total cost, the most significant are regulating ESs (on average $62 \%$ with variation from 41 to $83 \%$ ), the minimum share belongs to provisioning ( $13 \%$ with variation from 5 to $19 \%)$ and cultural $(25 \%, 1-54 \%)$ services Table 4).

These data weakly correlate with the valuation of ESs throughout Russia [40], where the proportion between provisioning, regulating, and cultural services is $5.7,94$, and $0.3 \%$. First of all, the difference is due to the increase in the contribution of cultural services, which logically reflect the specificity of the urban space. As noted in the literature, the benefits obtained across different scales of research often do not coincide [3].

As expected, the maximum cost of provisioning and regulating services is associated with natural landscape components typical of the Bitsevsky forest and is 30 to $40 \%$ higher compared to the cost of these services in courtyard and highway areas, respectively. Analysis of the contribution of vegetation and soil to provision- 
Table 4. Specific value of ecosystem services in different urban landscapes

\begin{tabular}{|c|c|c|c|c|}
\hline \multirow{3}{*}{ Service } & \multirow{3}{*}{ Estimated indicators } & \multirow{2}{*}{\multicolumn{3}{|c|}{$\begin{array}{c}\text { Specific value of the territory, } \\
\text { thousand rubles/ha }\end{array}$}} \\
\hline & & & & \\
\hline & & PRL & RL & RTL \\
\hline \multicolumn{5}{|c|}{ Provisioning } \\
\hline Genetic material of the biota & Abundance of soil biota & 2160 & 566 & 864 \\
\hline & Diversity of soil biota & \multicolumn{3}{|c|}{ No reliable valuation methods } \\
\hline Plant resources & Biomass stock & 189 & 87.9 & 110.3 \\
\hline Sum of provisioning services & & 2349 & 654 & 974 \\
\hline \multicolumn{5}{|c|}{ Regulating } \\
\hline Evaporation, air purification & Dust absorption by tree plantations & 134.8 & 47.2 & 60.7 \\
\hline Stability of masses, erosion control & $\begin{array}{l}\text { Woody and herbaceous plantations } \\
\text { on slopes }\end{array}$ & 26 & 3 & 0 \\
\hline $\begin{array}{l}\text { Filtration and accumulation of chemical ele- } \\
\text { ments in the ecosystem }\end{array}$ & Contents of heavy metals & 6000 & 4800 & 3600 \\
\hline & Organic carbon stock & 1400 & 1100 & 1300 \\
\hline Weathering and soil formation processes & Thickness of humified layer & \multicolumn{3}{|c|}{ No reliable valuation methods } \\
\hline Decomposition and fixation processes & Biological activity of soils & 13 & 3 & 2 \\
\hline $\begin{array}{l}\text { Climate regulation, removal of greenhouse } \\
\text { gases }\end{array}$ & Deposition of $\mathrm{CO}_{2}$ in woody plants & 168 & 58.8 & 75.6 \\
\hline Sustainable existence in the reserved state & Preservation of the profile of native soils & \multicolumn{3}{|c|}{ No reliable valuation methods } \\
\hline Sum of regulating services & & 7742 & 6012 & 5039 \\
\hline Vegetation-related ESs & & 517.8 & 196.9 & 246.6 \\
\hline Soil ESs & & 9573 & 6469 & 5766 \\
\hline Proportion between the costs of ESs of soil an & vegetation & 18 & 33 & 23 \\
\hline \multicolumn{5}{|c|}{ Cultural } \\
\hline $\begin{array}{l}\text { Physical (direct) use of landscape for various } \\
\text { purposes }\end{array}$ & $\begin{array}{l}\text { Recreation (walk, sports, presence } \\
\text { of paths and clearings) }\end{array}$ & 1925 & 3557 & 20.5 \\
\hline Entertainment & $\begin{array}{l}\text { Recreation and entertainment in the } \\
\text { park, nature festivals, sport races }\end{array}$ & 15 & 4000 & 0 \\
\hline Aesthetic enjoyment & $\begin{array}{l}\text { Sense of closeness to nature, inspiration } \\
\text { source }\end{array}$ & 350 & 250 & 0 \\
\hline Value of existence & Presence of natural park per se & 91 & 200 & 20.5 \\
\hline Sum of cultural services & & 2381 & 8007 & 42 \\
\hline Total ESs & & 12472 & 14673 & 6055 \\
\hline \multicolumn{2}{|c|}{ Proportion between provisioning, regulating, and cultural services ( $\%$ of the total value) } & $19: 62: 19$ & $5: 41: 54$ & $16: 83: 1$ \\
\hline
\end{tabular}

ing services attests to a dominant role of soil; The benefits generated by vegetation vary from 200 to 517 thousand rubles/ha, and the benefits from soil are from 5766.4 to 9573 thousand rubles/ha, i.e., $18-33$ times higher.

To simplify the calculation of the cost of soil ESs as suggested earlier [27], one can use a coefficient reflecting the ratio of the cost of soil to the cost of vegetation services.

The noted differences are primarily determined by the high cost of ESs provided by the functions of soils: "genetic material of soil biota" and "filtration and accumulation of chemical elements". The estimation of the size of "carbon stocks" is quite significant. Soil services are particularly costly, since human intellectual and technical costs to compensate for their natural functions are also very significant. The cost of ES "decomposition and fixation processes" is two orders of magnitude lower and varies from 2 to 13 thousand rubles/(ha year). However, if we compare it with the carbon sequestration in 40-year-old tree plantations, the recalculation for this period will give us about 500 thousand rubles, which is 2.5 times higher than the cost of this ES of green spaces.

Apparently, for assessing ESs associated with soil functioning in urban landscapes, the choice of soil parameters such as carbon stocks, the ability to accumulate pollutants, biological activity of soils, and the state of soil biota is more promising. Texture, density, reaction of the medium, and other soil properties are difficult to monetize, though they affect the properties listed above. This approach will make it possible to avoid double estimation of soil ESs [40]. 
The cost of the service "biomass reserves of the main plant resources" in different urban landscapes is not very high; it reaches 189 thousand rubles/ha in the PRL and is 50 and $30 \%$ lower in the RL and RTL, respectively. The costs of carbon sequestration by woody plants (59-168 thousand rubles/ha) and dust absorption (47-134 thousand rubles/ha) are comparable and are significantly lower than the cost of ESs of soils, which is determined, first of all, by the possibility of restoring this resource (woody plants) in a relatively short time. Soil as a complex system characterized by the long period of formation, is a long-restoring resource. Therefore, soil ESs of "preservation of the diversity of soil biota" and "preservation of the profile of natural soils" are, in fact, invaluable.

It should be noted that there is a problem of correct economic assessment of some regulating services. The cost of services for "filtration and accumulation of chemical elements" in comparison with services for "maintaining the processes of decomposition and fixation" and "climate regulation and removal of greenhouse gases" is orders of magnitude higher. This is due to the fact that services that can be replaced using human and technical capabilities are more expensive than those that have no analogues on the market. At the same time, the high cost of the service "filtration and accumulation of chemical elements" is due to the high price and complexity of the process of cleaning soil material from pollutants, and there is no market proposal to increase biological activity or sequester carbon directly at the assessment site. Therefore, the low cost of some regulating services should be perceived as underestimation, because the loss of such a service is irreplaceable in an artificial way.

Unexpectedly, the cost of cultural services of the Bitsevsky forest is estimated by the respondents as rather low (2381 thousand rubles/ha). Apparently, this is largely determined by the poor development of recreational facilities in this area. Obviously, the cultural significance of the PRL, which is located within the city, is underestimated. With insignificant investments into recreation infrastructure in the park, the increase in the cost of cultural services will be significant. The low cost of this block of services indicates that society has not yet accepted an idea of the great ecological value of park areas.

Cultural services in courtyard areas have the highest cost, three times higher than those in the PRL. For the RL, the recreation function is of particular importance (Table 1) and value (3557 thousand rubles/ha), which is reflected in the cost estimate of these services (8007 thousand rubles/ha), or $54 \%$ of the total cost of all services. An analogous situation was noted for the Yasnaya Polyana historical and cultural territory [36]. The high value of cultural services of the residential landscape is associated with its location in the place of consumption of these services, that is, in close proximity to the population of residential buildings, shop- ping, entertainment centers, etc. The proximity to the center of consumption always leads to an increase in the demand and cost of services, including ecosystem services. The minimum cost of cultural services for the population is noted for the RTL: only 42 thousand rubles/ha. This type of landscape is clearly underestimated, since the aesthetic perception of these territories is part of the aesthetics of the urban environment.

The assessment of cultural services is based on the polling of respondents, taking into account the subjective opinion and personal experience of each beneficiary at a given time. Therefore, its results are limited in time and show the demand for landscape services at the current moment, that is, in the short term. The valuation of regulating and provisioning services is based on other economic valuation methods and uses specific biological, physical, and chemical parameters of the environment. The fluctuation of the estimated parameters of inanimate nature is less than the fluctuation of the mood of people as consumers of certain services. Therefore, the results of the assessment of regulating and provisioning services show a more stable size and value of the landscape in the medium and long term.

\section{CONCLUSIONS}

The results obtained in this study allow us to rank the studied urban landscapes in terms of the benefits from their ecosystem services as follows: RL > PRL > RTL. The maximum value of courtyard areas is associated with their active participation in the implementation of cultural services and successful implementation of environmental services. The cost of ESs of the forest park is somewhat lower (with a high cost of the natural block and a cost of the cultural block), and the cost of residential-transport landscape is significantly (two times) lower because of the low value of cultural services. When assessing ecosystem services provided by urban landscapes, two main features have been established: a significant participation of cultural ESs (up to 50\%) against the background underestimation of ecological functions and services and, accordingly, the ecological significance of landscapes.

Undoubtedly, the cost estimate of the ESs of urban landscapes is of great practical importance for urban planning and should be used as a tool for organizing the urban environment and regulating construction work and the ecological state of urbanized territories. The most valuable in terms of provisioning and regulating services is the Bitsevskiy Les forest park, the preservation of which should be a priority when organizing urban space. For residential landscapes characterized by the minimum cost of ESs of the ecological block, it is necessary to develop approaches and measures to optimize, first of all, soil properties and conditions of soil cover functioning, which should be reflected in the standards for the formation of soils and measures for the improvement of the city. The cost of 
restoration of ES performed by the soil is very high and determines the need for maximum preservation of the soil cover during the design and organization of urban landscapes. In particular. the area of sealed territories should be regulated on a legislative basis. To estimate the cost of urban landscapes, ESs of soils should be taken into account, because their value is comparable to or up to two times higher with the cost of urban green spaces. Some of soil ESs are really invaluable because of the complexity of restoration of disturbed soils and impossibility to fully compensate for their ecological functions.

\section{FUNDING}

This study was performed within the framework of state assignment no. 121040800321-4 (Indicators of Transformation of the Biogeochemical Cycles of Biogenic Elements in natural and anthropogenic landscapes) and the Development program of the Interdisciplinary Scientific and Educational School "Future of the Planet and Global Environmental Change" at the Lomonosov Moscow State University.

\section{CONFLICT OF INTEREST}

The authors declare that have no conflicts of interest.

\section{OPEN ACCESS}

This article is licensed under a Creative Commons Attribution 4.0 International License, which permits use, sharing, adaptation, distribution and reproduction in any medium or format, as long as you give appropriate credit to the original author(s) and the source, provide a link to the Creative Commons license, and indicate if changes were made. The images or other third party material in this article are included in the article's Creative Commons license, unless indicated otherwise in a credit line to the material. If material is not included in the article's Creative Commons license and your intended use is not permitted by statutory regulation or exceeds the permitted use, you will need to obtain permission directly from the copyright holder. To view a copy of this license, visit http://creativecommons.org/licenses/by/4.0/.

\section{REFERENCES}

1. L. I. Abramova and N. A. Berezina, Summer Botanical Practice (Moscow State Univ., Moscow, 1988) [in Russian].

2. O. Yu. Baranova, O. V. Semenyuk, K. S. Bodrov, and G. V. Stoma, "Ecosystem services and a normative methodological approach for the ecological and economic assessment of a natural site in the context of urban planning," Akad. Vestn. Ural. Nauchno-Issled. Proekt.Konstr. Inst. UralNIIProekt 45 (2), 21-27 (2020).

3. S. N. Bobylev, "Approaches to evaluation of ecosystem services at the city level and payment mechanisms," $\mathrm{Na}$ Puti Ustoichivomu Razvit. Ross., No. 70, 3-12 (2014).
4. S. N. Bobylev and V. M. Zakharov Ecosystem Services and Economics (Center of Russian Ecological Policy, Moscow, 2009) [in Russian].

5. E. V. Bondarenko, Candidate's Dissertation in Biology (Moscow, 2016).

6. A. F. Vadyunina and Z. A. Korchagina, Physical Analysis of Soils (Agropromizdat, Moscow, 1986) [in Russian].

7. L. A. Vorob'eva, Theory and Practice of the Chemical Analysis of Soils (GEOS, Moscow, 2006) [in Russian].

8. M. I. Gerasimova, M. N. Stroganova, N. V. Mozharova, and T. V. Prokof'eva, Anthropogenic Soils: Genesis, Geography, and Reclamation (Oikumena, Smolensk, 2003) [in Russian].

9. Methods of Soil-Zoological Studies, Ed. by M. S. Gilyarov (Nauka, Moscow, 1975) [in Russian].

10. Geography and Monitoring of Biological Diversity, Ed. by N. S. Kasimov, (Scientific and Education-Methodological Center, Moscow, 2002) [in Russian].

11. G. V. Dobrovol'skii and E. D. Nikitin, Ecological Functions of Soils (Moscow State Univ., Moscow, 1986) [in Russian].

12. V. A. Dogel', Zoology of Invertebrates (Vysshaya Shkola, Moscow, 1981) [in Russian].

13. A. S. Zhetukhin, R. B. Sandlerskii, and Yu. G. Puzachenko, "The role of biospheric nature reserves in assessment of the potential of ecosystem services in a region," Izv. Samar. Nauchn. Tsentra, Ross. Akad. Nauk 1 (1), 1508-1516 (2011).

14. L. L. Shishov, V. D. Tonkonogov, I. I. Lebedeva, and M. I. Gerasimova, Classification and Diagnostic System of Russian Soils (Oikumena, Smolensk, 2004) [in Russian].

15. D. E. Konyushkov, "The development of the concept of ecosystem services: a review of foreign publications," Byull. Pochv. Inst. im. V.V. Dokuchaeva, No. 80, 2649 (2015).

16. V. A. Kuznetsov, Candidate's Dissertation in Biology (Moscow, 2015).

17. V. A. Kuznetsov, I. M. Ryzhova, and G. V. Stoma, "Changes in the properties of soils of Moscow forest parks under the impact of high recreation loads," Eurasian Soil Sci. 50, 1225-1235 (2017).

18. V. A. Kuznetsov, G. V. Stoma, and K. S. Bodrov, "The condition of the mesopedobiont community in Moscow forest parks as an indicator of the recreational load and the formation of impact zones along footpaths," Moscow Univ. Soil Sci. Bull. 69, 40-48 (2014).

19. O. A. Makarov, Why Soil Should be Evaluated? State/Quality of Soil: Assessment, Standardization, Management, and Certification (Moscow State Univ., Moscow, 2003) [in Russian].

20. O. E. Medvedeva, "Algorithm for the price evaluation of ecosystem services in natural areas of Moscow," Na Puti Ustoichivomu Razvit. Ross., No. 70, 13-32 (2014).

21. Practical Manual on Soil Microbiology and Biochemistry, Ed. by D. G. Zvyagintsev (Moscow State Univ., Moscow, 1991) [in Russian].

22. E. D. Nikitin, The Basis of Life on Earth: Soil-RussiaCivilization (MAKS Press, Moscow, 2010) [in Russian].

23. R. A. Perelet, "Zu einigen aktuellen Aspekten der Bewertung von Ökosystemgütern und Dienstleistungen in Russland," in TEEB-Prozesse und Ökosystem-Assessment in Deutschland, Russland und Weiteren Staaten des Nördlichen Eurasiens, BfN-Skripten no. 372, Ed. by 
K. Grunewald, O. Bastian, und A. Drozdov (Bundesamt für Naturschutz, Bonn, 2014), Ch. 3.1, pp. 82-91.

24. E. V. Potapova, "Ecosystem services of green areas of the settlements," Byull. Nauki Prakt., No. 9 (10), 3641 (2016).

25. Soil, City, Ecology, Ed. by G. V. Dobrovol'skii (Foundation for Economic Literacy, Moscow, 1997) [in Russian].

26. J. G. Puzachenko, R. B. Sandlersky, A. G. Sankovski, et al., "Application of multispectral remote sensing techniques for evaluating maintenance, stability and regulatory ecosystem services," in Erfassung und Bewertung von Ökosystemdienstleistungen (ÖSD)_Erfahrungen, insbesondere aus Deutschland und Russland, BfNSkripten no. 373, Ed. by K. Grunewald, O. Bastian, und A. Drozdov (Bundesamt für Naturschutz, Bonn, 2014), Ch. 3.2, pp. 118-133.

27. O. V. Semenyuk, K. S. Bodrova, G. V. Stoma, and S. A. Yakovlev, "Estimating the ecosystem services' value of the Bitzevsky Forest Natural Park," Moscow Univ. Soil Sci. Bull. 74, 111-117 (2019).

28. G. V. Stoma, "Ecological status of soils and tree plantations of residential landscapes in Moscow," Moscow Univ. Soil Sci. Bull. 71, 35-41 (2016).

29. G. V. Stoma and E. V. Akhadova, "Characteristics and ecological status of soils in the area of Moscow State University," Moscow Univ. Soil Sci. Bull. 70, 29-35 (2015).

30. G. V. Stoma and L. V. Romanova, "Ecological state of soils and tree vegetation in urban park-recreational landscapes (based on the example of Catherine Park in Moscow)," Moscow Univ. Soil Sci. Bull. 74, 146-153 (2019).

31. M. N. Stroganova, T. V. Prokof'eva, A. N. Prokhorov, L. V. Lysak, A. P. Sizov, A. S. Yakovlev, "Ecological status of urban soils and economic evaluation of lands," Eurasian Soil Sci. 36, 780-787 (2003).

32. Structural and Functional Role of Soil in Biosphere, Ed. by G. V. Dobrovol'skii (GEOS, Moscow, 1999) [in Russian].

33. V. M. Telesnina, O. V. Semenyuk, L. G. Bogatyrev, and A. I. Benediktova, "Features of the groung cover and forest litter of artificial lime plantations depending on the nature of care," Moscow Univ. Soil Sci. Bull. 73, 45-52 (2018).

34. A. A. Tishkov, "Ecosystem services of landscapes as one of general strategic resources of Russia," in Strategic Resources and Conditions of Sustainable Development of Russian Federation and Its Regions (Institute of Geography, Russian Academy of Sciences, 2014), pp. 70-88.

35. T. V. Tikhonova, "Ecosystem services: role in regional policy and Evaluation approaches," Izv. Komi Nauchn. Tsentra, Ural. Otd., Ross. Akad. Nauk, No. 3 (27), 134-142 (2016).

36. E. V. Tsvetnov, O. A. Makarov, K. L. Grigoryan, and V. S. Krasil'nikova, “Assessment of ecosystem services of historical and cultural lands (using example of the Yasnaya Polyana Museum-Estate of L.N. Tolstoy)," Moscow Univ. Soil Sci. Bull. 73, 175-180 (2018).

37. Ecological Functions of Urban Soils, Ed. by Kurbatov and V. N. Bashkin (Madzhenta, Smolensk, 2004) [in Russian].

38. Ecology of a City, Ed. by A. S. Kurbatova, (Nauchnyi Mir, Moscow, 2004) [in Russian].

39. Ecosystem Services of Russia. Prototype of the National Report, Vol. 1: Terrestrial Ecosystems Services, Ed. by
E. N. Bukvareva and D. G. Zamolodchikov (Biodiversity Conservation Center, Moscow, 2016).

40. Ecosystem Services of Russia. Prototype of the National Report, Vol. 2: Biodiversity and Ecosystem Services: Accounting Principles in Russia, Ed. by E. N. Bukvareva and T. V. Sviridova (Biodiversity Conservation Center, Moscow, 2020).

41. Common International Classification of Ecosystem Services (CICES), 2013. https://cices.eu. Accessed October 19, 2018.

42. R. Costanza, R. d'Arge, R. de Groot, et al., The value of the world's ecosystem services and natural capital," Nature 387, 253-260 (1997).

43. P. Elsasser, Umweltökonomische Bewertung der Ökosystemleistungen von Wäldern-Methodik und Anwendungsperspektiven (Bundesamt für Naturschutz, Bonn, 2014), pp. 278-293.

44. U. Grewer, L. Bockel, L.-S. Schiettecatte, and M. Bernoux, Ex-Ante Carbon-Balance Tool (EX-ACT): Quick Guidance (UN Food and Agriculture Organization, Rome, 2017).

45. K. Grunewald and O. Bastian, "Bewertung von ÖSD in Naturschutzgebieten (Natura 2000) und Agrarlandschaften-Methodik und Fallbeispiele," in Erfassung und Bewertung von Ökosystemdienstleistungen (ÖSD): Erfahrungen, Insbesondere aus Deutschland und Russland, Ed. by K. Grunewald, O. Bastian, A. Drozdov, and V. Grabovsky (Bundesamt für Naturschutz, Bonn, 2014), pp. 238-263.

46. L. Madrid, E. Díaz-Barrientos, R. Reinoso, and F. Madrid, "Metals in urban soils of Seville: seasonal changes and relations with other soil components and plant contents," Eur. Soil Sci. 55 (2), 209-217 (2004).

47. Millennium Ecosystem Assessment. Ecosystems and Human Wellbeing: Synthesis Report (Island Press, Washington, DC, 2005).

48. F. Müller and B. Burkhard, "An ecosystem-based framework to link landscape structures, functions and services," in Proceedings of Meeting Future Demands for Landscape Goods and Services "Multifunctional Land Use” (Springer-Verlag, Berlin, 2007), pp. 37-64.

49. S.-J. Park, Z. Cheng, H. Yang, E. E. Morris, M. Sutherland, et al., "Differences in soil chemical properties with distance to roads and age of development in urban areas," Urban Ecosyst. 13 (4), 483-497 (2010).

50. Payments for ecosystem services getting started: a primer, Forest Trends, Katoomba Group, UNEP, 2008. http://www.unep.org. Accessed October 23, 2018.

51. R. V. Pouyat, I. D. Yesilonis, J. Russell-Anelli, and N. K. Neerchal, "Soil chemical and physical properties that differentiate urban land-use and cover types," Soil Sci. Soc. Am. J. 71 (3), 1010-1019 (2007).

52. B. C. Scharenbroch, J. E. Lloyd, and J. L. JohnsonMaynard, "Distinguishing urban soils with physical, chemical, and biological properties," Pedobiology 49 (4), 283-296 (2005).

53. IUSS Working Group WRB, World Reference Base for Soil Resources 2014, Update 2015, International Soil Classification System for Naming Soils and Creating Legends for Soil Maps, World Soil Resources Reports No. 106 (UN Food and Agriculture Organization, Rome, 2015.

Translated by D. Konyushkov 